\title{
Credit Provision Strategy during Financial Crisis Using Bank Accounting Data
}

\author{
Aggelopoulos Eleftherios ${ }^{1}$, Giannopoulos Vasilios $^{2}$ \& Mpourou Evgenia ${ }^{3}$ \\ ${ }^{1}$ PhD., Adjunct Lecturer in Financial Accounting, Department of Business Administration, University of Patras, \\ University Campus, 26504, Rio - Patras, Greece \\ 2 PhD., Department of Business Administration, University of Patras, University Campus, 26504, Rio - Patras, \\ Greece \\ ${ }^{3}$ M.Sc, Department of Economic, University of Patras, University Campus, 26504, Rio - Patras, Greece \\ Correspondence: Aggelopoulos Eleftherios, PhD., Adjunct Lecturer in Financial Accounting, Department of \\ Business Administration, University of Patras, University Campus, 26504, Rio - Patras, Greece. Tel: 30-69-721-9741
}

Received: September 27, 2016

Accepted: October 26, 2016

Online Published: October 27, 2016

doi:10.5430/afr.v5n4p137

URL: http://dx.doi.org/10.5430/afr.v5n4p137

\begin{abstract}
This paper examines the changes in credit provision for the Greek Banking Sector before and during the financial crisis. Also, it investigates the impact of specific loan characteristics in shaping the overall interest rate of new and existing business loans. A data set with monthly accounting data of Greek Banks for the period January 2003 to June 2011 is utilized, thus incorporating the crisis effects. The study findings reveal the beginning of the credit crunch at the third quarter of 2009. As far as new loans are concerned, it was found that large loans are priced less than the small ones. Moreover, the results show the greater and positive contribution of small loans to the derivation of the total lending interest rate. Furthermore, it is found that the bargaining power of large borrowers during the crisis causes a negative impact of large loans on the total interest rate. Finally, it is shown that in the existing loan portfolio, the crisis significantly reduces the effect of short-term loans, while simultaneously intensifies the positive effect of medium and long-term loans. The findings have important managerial implications for bank managers and policymakers.
\end{abstract}

Keywords: Credit provision, Banks, Crisis

JEL classification: G21, M41, C23

\section{Introduction}

The recent global financial crisis, which started in 2007 in the US financial system, affected the entire world economy and the global banking system. Its intensity has hit banks worldwide by increasing uncertainty about the quality of the borrower (increased information asymmetry) and the simultaneous reduction of available bank funding. The purpose of this paper is to investigate: Firstly, the impact of specific loan characteristics (size, pricing, type of loan, duration) and other variables (time, existing and new funding) on the total interest rate of corporate loans; and secondly, the evolution of credit (credit growth) in the Greek banking system, the changes in interest rates on new and existing loans, as well as the relationship of the escalation of the provided credit (credit rationing) with the fluctuation of interest rate. Also, this paper examines the credit crunch indications (credit crunch) in the domestic banking system as a result of the financial crisis.

To examine the behavior of the lending interest rate, the paper uses time series of monthly data (interest rates amounts) of corporate loans, granted by the Greek Banking System. The study period includes both a period of growth and a recession period that followed the financial crisis in Greece. In particular, it covers the period from January 2003 to June 2011 and analyzes the reaction of the domestic banking system during the recent crisis in terms of variations on corporate loans interest rates. The Greek economy, suffering from adverse recession effects and characterized by similar banking operations with other EU peripheral countries (i.e. a traditional business model with deposit taking and loan granting operations), seems to be the ideal case study to explore changes in credit provision given the occurrence of crisis. In view of the above, the value added of this paper is that it stresses the importance of the thorough understanding of changes in bank credit strategies due to crisis for designing appropriate policies aiming to ensure financial stability in Greece and in other euro area periphery economies in the post crisis era.

The study main findings are: Firstly, with respect to bank's credit provision, a differentiation of the policy due to the 
financial crisis is observed. In particular, up to May 2008 (growth period), a rapid credit growth is recorded given the increased new lending levels (i.e. $11 \%$ was the average annual increase rate on new lending balances; Bank of Greece, 2010). The latter, illustrates the expansive strategy followed - without exception- by all credit institutions in the country, aiming to increase their loan portfolio and thus acquire a larger market share in the Greek and Balkan market. The positive credit growth was maintained until the fall of 2009, where a slowing credit growth was recorded and then it was converted to a credit contraction (October 2009, credit crunch). Secondly, as regards the interest rates on new business loans, an upward trend until the autumn of 2008 is recorded as a result of the economic growth. There is a sharp decrease on interest rates from October 2008 onwards until the November 2009, where an increased trend is recorded again, as a result of the banks' policy to reprice the loan portfolio in order to cope with the rising funding costs and credit risk. Thirdly, as regards interest rates of the existing loan portfolio, no significantly volatility until the middle of 2006 is observed. Thereafter, an upward trend is observed until the fall of 2008 , while afterwards a steep downward trend is recorded, due to a decline in the base market interest rates, such as Euribor and subsequently to the contractual rate of each loan (i.e. each loan is priced as the sum of the base interest rate and a spread that bank defines according to the creditworthiness of the borrower). From the end of 2009 and onwards, a gradual recovery in the level of interest rates is observed, thus demonstrating that the policy of banks to reprice the loan portfolio started to have positive effects. Thirdly, the econometric results of the paper reveal the credit strategy that domestic financial institutions followed, as regards the management of the existing loan portfolio, from the beginning of the crisis until the end of the reporting period. During the crisis, the participation and influence of specific loan characteristics in the formation of the overall interest rate was different. The differentiation of the contribution of new loans is due to the bargaining power of borrowers, while for existing loans to the alteration of bank credit strategy. In the new credit production, small loans presented a greater and more positive contribution to the formation of the overall interest rate, as opposed to large loans that presented a negative impact during the crisis. In the existing loan portfolio, the impact of short-term loans is reduced significantly, while the positive effect of medium rem loans in determining the overall rate is more than doubled. Finally, the paper investigates the use of complementary strategies by credit institutions during the crisis and detects a change of direction in credit policy, with a focus on qualitative evaluation and more intensive monitoring and proactive control of their loan portfolios.

The structure of the paper is as follows: The next section presents the literature review while Section 3 gives an overview of the Greek Banking Sector. Section 4 explains the data and the empirical results. The last section concludes the paper and discusses the main findings and the implications of the study.

\section{Literature Review}

As a result of the crisis, banks have reduced credit and set stricter credit criteria, thus diversifying their lending policy. There are relatively few studies to investigate the changes in the supply of loans and the effect of limiting the credit to total lending rate during crises. In addition, there is no extensive literature on the measurement and restriction mechanism of bank credit and the effect of specific characteristics (loan characteristics, bank effects) on the part of the loan supply (supply side effects) in shaping the bank credit policy. The limited number of studies on the relationship of loan data and credit booms is confirmed in the discussion paper by Dell'Ariccia et al. (2008). As evidenced in the article, most studies focus on the impact of changes on macroeconomic indicators at the bank credit level. Previous research mainly examines the correlation of economic cycles and bank credit cycles (Bernanke \& Lown, 1991; Peek \& Rosengren, 2000; Black \& Strahan, 2002; Calomiris \& Mason, 2003), and more generally the boundary between financial development and economic fluctuation. In this context, some researchers argue that the quality of bank loans may deteriorate during periods of economic growth and expansion. When the economy is strong and the default rates are low, banks can expand their loan portfolio quickly and above acceptable levels. This excess lending activity creates adverse problems and leads to an increase in the volume of bad loans (Asea \& Blomberg, 1998), which sets the stage for higher than expected default rates, causing then an excessive contraction of bank lending. The economy then slows down again. However, the credit expansion and the attitude of banks to lend, usually works procyclical. The adoption of stricter lending criteria by banks is the natural bank reaction given the increased credit risk in times of economic slowdown. Instead, banks often expand their lending and relax the credit policy criteria during the expansion period (English \& Reid, 1994; Weinberg, 1995). Such a systematic alteration between stringent and relaxed lending criteria during economic cycles has been observed in United States (Asea \& Blomberg, 1998), Scandinavia (Holmstrom \& Tirole, 1997), in Germany (Nehls \& Schmidt, 2004). A reduction in credit growth usually follows the economic downturn as a result of the focus of banks on the closing monitoring of borrowers and the slowing of business credit demand since firms try to reduce their debt burden when revenues are limited.

In the literature the notion of credit crunch is used to describe the reduction in the volume of bank lending which is also accompanied with a tightening of credit criteria. The Asea and Blomberg (1998) investigated the lending 
behavior of banks using 2,000,000 loan contracts form 580 banks in the period 1977-1993. They showed that banks are changing lending standards and policies systematically throughout economic cycles. They also found that during recessions the bank demand for collateral from borrowers increases, while it decreases during expansion. The determinants of bank lending and the alteration of bank credit strategy during the recent crisis are presented on the paper of De Haas and Van Horen (2009a, 2009b). A data set of 31,000 syndicated loans from 65 developed and emerging countries during 2005-2009 was used to examine how banks have changed their lending standards during the current financial crisis. The results revealed that during the crisis the banks not only reduced the credit, but also increased the control and monitoring of their portfolio. This confirms empirical findings that during the financial crisis banks become more selective in lending to new customers (Ivashina \& Scharfstein, 2009). Moreover, during the crisis, banks put strict lending standards, especially for unsecured loans while loans to new customers and specifically unsecured loans are reduced significantly. The changes in the credit policy of the banks also have tested by Guttentag and Herring (1984) which showed that cognitive biases by lenders, including overstated information about the value of collateral, can lead to a restriction of credit (credit rationing) depending on the prevailing economic conditions. The Rajan (1994) shows that this type of management may generate cyclic behavior failure-market failure. Finally, Burgstaller and Scharler (2009) examined the shift of market interest rates on bank loans using aggregated data for the United Kingdom. They found that changes in money market rates can only partly influence lending rates. They also concluded that the banks can manage fluctuations in loans demand in a great extent, and that they provide the appropriate credit to their clients in times of liquidity shortage.

\section{The Evolution of the Greek Banking System}

As Greece entered the Eurozone (2001), the Greek economy showed remarkable growth rates which boosted the development of the domestic banking sector. In particular, in the growth years till 2008 the Greek Banks (i.e. 35 banks were operating in Greece in 2009, with 19 being commercial banks and 16 cooperative banks) followed an ambitious expansion strategy expanding their networks in Greece and in Southeastern European countries. Instead of investing their assets in toxic products, they strongly participated in public financing acquiring state bonds and short-term securities. At the same time, based on the low interest rates of the ECB, they followed an aggressive credit policy massively lending to households and enterprises. However, state-led demand based on rising public deficit and debt created unfavorable economic conditions. In 2008, the recession led to the collapse of the inter-bank confidence with crucial liquidity and performance implications of domestic banking institutions. At the macroeconomic level, a disclosure by the Greek finance minister on 2009 that the budget deficit is expected to reach $12.5 \%$ of GDP led to a downgrading of the creditworthiness of the Greek economy and a significant widening of the yield spread between Greek and German bonds. The Gross Domestic Product (GDP) declined for the first time in 2009 by $3.2 \%$ and $5.48 \%$ in 2010 . The general government deficit in 2009 reached $15.7 \%$ of GDP $(9.8 \%$ of GDP in 2008 ) and the primary deficit to $10.5 \%$ of GDP (4.8\% of GDP in 2008). As a result, the gross debt as a percentage of GDP increased from 112.9\% in 2008 to $129.7 \%$ in 2009 and reached 148.3\% in 2010 (Bank of Greece, 2010). This adverse environment negatively affected the performance of the Greek banking system. The number of non-performing loans increased gradually from 2008 onwards. In particular, the overall NPL ratio of Greek banks rose to $7.7 \%$ in 2009, from $5.0 \%$ in 2008 and more than doubled in 2010 from its 2008 levels.

Given the unstable macroeconomic environment, the Greek banking industry would seem to be an ideal choice for a case study of the investigation of changes in credit provision during crisis years.

\section{Data and Methodology}

\subsection{Data}

The data set generally includes accounting information related to bank loans, published by the Bank of Greece (i.e. Monthly Statistical Bulletin Bank of Greece http://www.bankofgreece.gr). In particular, monthly data are used for the balances and interest rates of both existing and new granted corporate loans, over the period 2003 to 2011. This study examines the statistical significance of the effect of specific loan characteristics in the lending rate level both before and during the crisis, trying to extract the critical factors that determine interest rate variations. This study is based on the assumption that both macroeconomic variables and specific loan characteristics affect the credit provision reduction and the derived results vary between the different categories of loans.

The paper uses time series data (monthly values) for all Greek commercial banks, covering the period January 2003 to June 2011. That total period includes both an expansion period and a recession period.

\subsection{Methodology}

To examine how the loan rate charged by banks changes over time, the following pooled time-series cross-sectional model is fitted by regressing the loan rate on loan characteristics, bank fixed effects and time effects. In particular, 
two linear regression models are utilized, following the paper of Kwan (2010). In each model, the dependent variable (total contractual interest rate) differs depending on the status of loan (new loan - current loan). Appendix A and Appendix B present the descriptive statistics of the examined variables along with the depiction of the residuals, for each regression model. The basic regression model is:

$$
Y_{i j t}=a X_{i j t}+\sum \lambda_{t} \operatorname{TIME}_{t}+\sum \mu_{j} \text { Bank }_{j}+e_{i t}
$$

Where: Yijt is the interest rate on loan $i$ made by bank $j$ at time $t, X i j t$ is a vector of loan $i$

characteristics, Time is the time effect dummy, Bank is the bank fixed effect dummy, and eit is the residual. The bank fixed effect controls for bank-specific factors including its production function and local market competition. The coefficients of the time effect dummies capture the time-specific factors, mostly the level of interest rates in the economy.

In particular, the first regression evaluates the pricing policy of banks for granting new loans (total interest rate for new loans) by regressing the overall interest rate over the specific loan characteristics, while it introduces a dummy variable to identify the impact of the crisis on specific loan characteristics. The specific loan characteristics include:

\section{LOANSIZE = Log (loan size);}

\section{COMMIT = Rate for commit and non-commit loans;}

\section{D = Dummy variables equal 1 after 2008M8, zero otherwise;}

In the same manner, in order to examine the evolution of interest rates on existing loans of credit institutions, the overall interest rate of existing loans is regressed over specific loan characteristics. Thus, the specific loan characteristics at the second regression are:

\section{LOAN DURATION = Rate of loan duration;}

\section{D = Dummy variables equal 1 after 2008M8, zero otherwise;}

The stepwise methodology is described below: Initially, the development of business credit (credit growth) in the Greek Banking System is estimated, through analyzing the monthly percentage change in corporate loans from year to year. Then, the variation of the lending interest rate, separately for existing corporate loans and new loans, is presented. Afterwards, the correlation between loan specific characteristics and the interest rate is examined through estimating the above models.

\section{Results}

\subsection{Interpretation of the Evolution of Times Series (Loans Balances, Interest Rates)}

Following the stepwise methodology, Figure 1 depicts the evolution of changes in loan balances for both new and existing loans. It is observed a positive credit growth until the end of 2008, where a slowdown took place and converted into a credit crunch (credit crunch) in 10/2009. The credit crunch peaked in 01/2010 and maintained its downward until the end of the examined period.

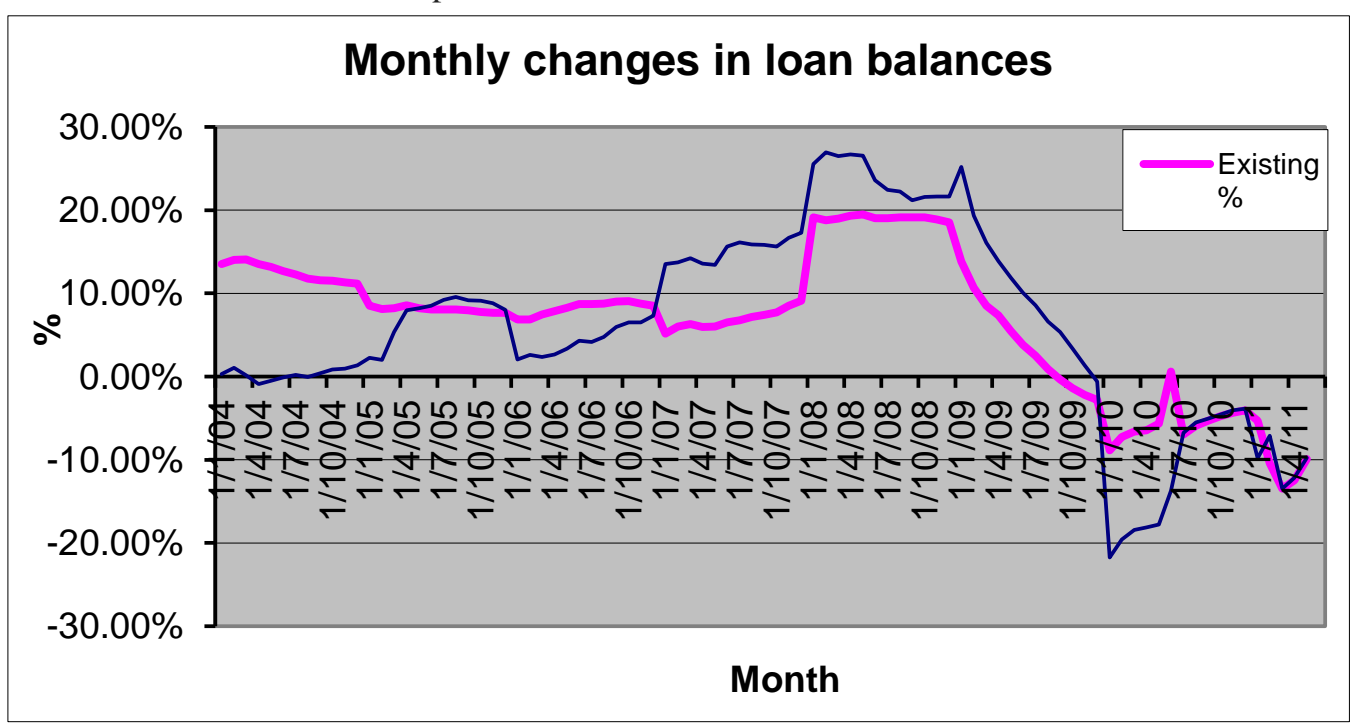

Figure 1. Depiction of monthly changes in loan balances 
Moreover, Figure 2 depicts the trend of interest rates on new loans that were granted through the examined period. It is observed an upward trend until the autumn of 2008 (boom). Then, a rapid decline in interest rates from 10/2008 is recorded, which leads the trend line of the base rate of both the ECB and interbank rates (euribor). From 10/2008 onwards, an upward trend is highlighted, as a result of the increased margin that banks charged to borrowers.

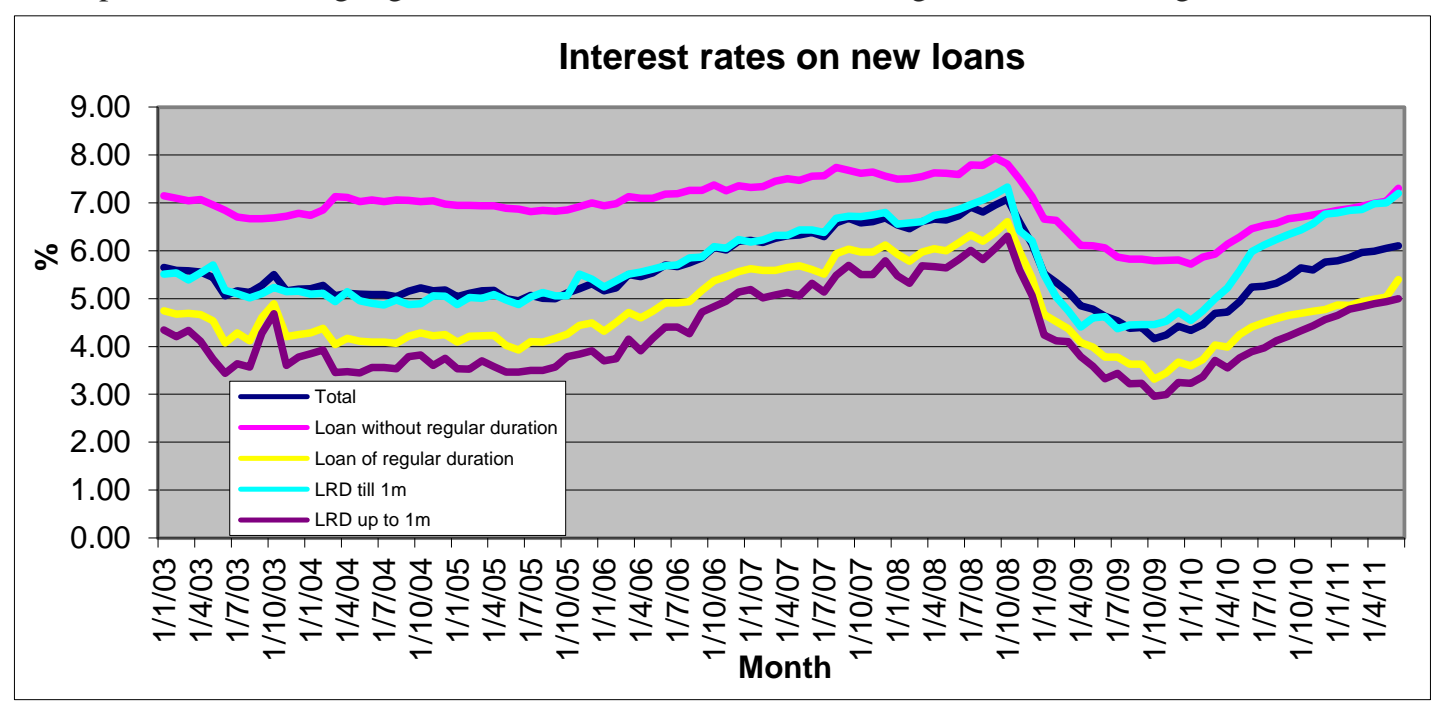

Figure 2. Depiction of the interest rates on new loans

Finally, Figure 3 presents the evolution of the interest rates on the existing loan portfolio. It is observed a steady trend until mid-2006 and afterwards an increased trend until the fall of 2008 as a result of the higher base rates. Then a steep downward trend until the end of 2008 is recorded due to the rapid decline in base interest rates, although banks started that period an attempt to reprice the loan portfolio. At the end of 2009 and onwards, a modest recovery in the level of interest rates is observed as a result of the bank management actions to increase the contractual interest rates of the existing loans.

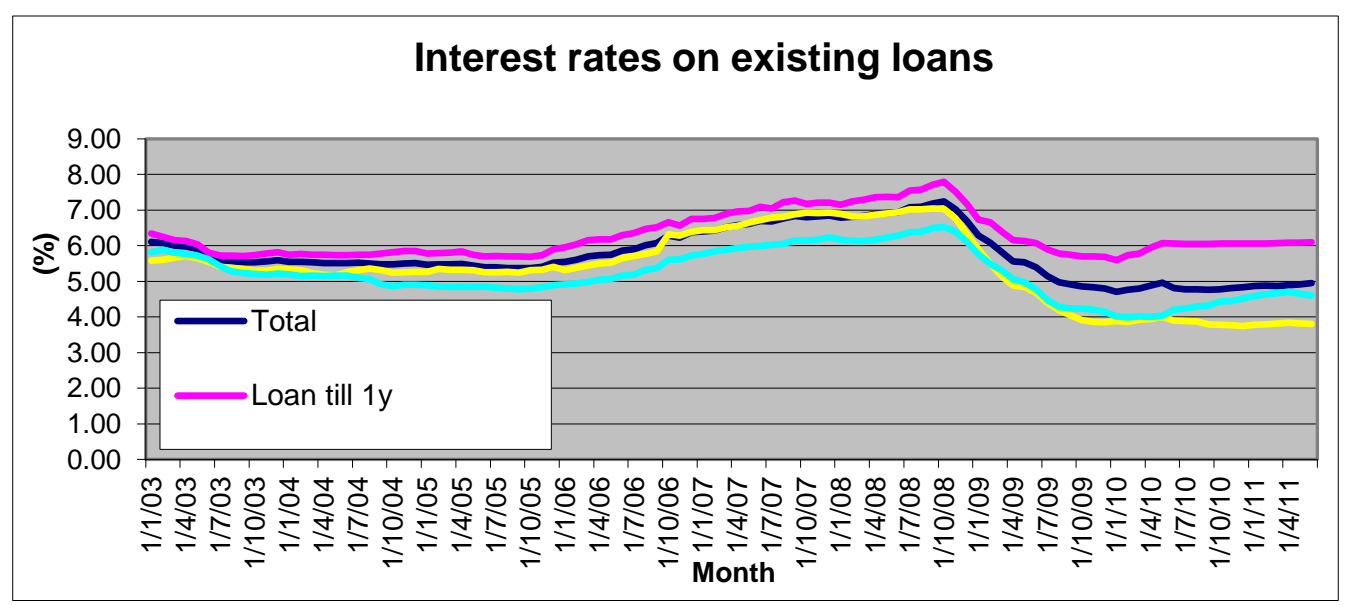

\subsection{Regression Results}

Below are the results of the estimated two regressions, as presented above. In table 1 the results of the first regression are presented. Initially, it is observed that the results are statistically significant. Next, the effect of the individual independent variables is examined. Regarding the amounts of loans up to one million euro (small business loans), it is observed that the coefficients (i.e. before and during the crisis), are statistically significant (as determined by the value of the statistical t-student). In particular, it is observed that in the expansion period the correlation between the total amount of small loans and the total interest rate on loans is negative, which is justified by the intense competition that characterized the market that period. During the crisis the effect of the amount of small new loans on interest rate is positive. This evidence demonstrates that the response of banks to the impact of the economic 
crisis in the Greek economy, is reflected to an increase in overall interest rate on small loans, as in these cases the negotiating ability of borrowers is reduced.

The above findings are reversed by studying the effect of the amount of loans (with a balance more than 1 million) on determining the overall rate of loans. During the expansion period the effect of the amount of these loans is positive since the overall pricing of these loans was already extremely low. During the crisis, the effect is negative, due to the rapid reduction of the reference interest rates (i.e. Euribor) and the fact that large customers present high bargaining power.

The next examined factor that is expected to determine the overall total interest rate of loans, is the type of the loan product. A distinction between loans with a specific maturity and those without a specific maturity namely credit and revolving accounts, is made. In particular, the effect of interest rates of the individual categories in determining the overall rate on loans, is examined. During the expansion period, the positive correlation of both loan categories with the dependent variable is confirmed. The effect of loans with a specific maturity is almost double than that of loans without a defined maturity. As regards the crisis period, although the above associations are being inversed, the coefficient are not statistically significant.

Table 1. Results of pooled time-series cross-section regression, 2003:M1-2011:M6 (Fixed-effect and time-effect coefficients not reported)

\begin{tabular}{lll}
\hline Variable & Coefficient & t-statistic \\
\hline Constant & 0.073 & 0.353 \\
Loan till 1 million & -0.175 & $-4.080^{* * *}$ \\
Loan till 1 million $* D$ & 0.254 & $4.790^{* * *}$ \\
Loan up to 1 million & 0.142 & $4.893^{* * *}$ \\
Loan up to 1 million $* D$ & -0.190 & $-3.978^{* * *}$ \\
Commit Rate & 0.337 & $7.328^{* * *}$ \\
Commit Rate $* D$ & -0.078 & -0.895 \\
Non commit rate & 0.686 & $37.500^{* * *}$ \\
Non commit rate $* D$ & 0.046 & 0.802 \\
$\boldsymbol{R}^{2}$ & 0.996 & \\
Observations & 102 & \\
\hline
\end{tabular}

Notes: Dependent variable: Total rate, Independent variables: Loan till 1 million, Loan up to 1 million, commit rate, non-commit rate, D: dummy variable taking the value of 1 for crisis, 0 otherwise.

The second regression correlates the total rate of existing commercial loans to individual categories of loans depending on the term of repayment. As mentioned above, a distinction of loans with a short term maturity (i.e. up to one year), a medium term maturity (duration of 1-5 years) and long term maturity (over 5 years), is adopted. As regards the short-term maturity existing loans, the correlation rate of these loans to the total rate of the existing commercial loan is positive and statistically significant. This correlation is expected during the expansion period since short-term loans are generally characterized by higher interest rates. During the crisis period, the positive correlation between short-term loans and overall interest rate on loans decreased significantly. This result shows that crisis decreases the generally positive effect of short-term loans on the overall rate of existing commercial loans.

As regards the medium term maturity existing loans, the effect of these loans in determining the overall lending interest rate is generally positive and statistically significant throughout the period considered. Studying the individual sub periods, it is observed that the effect is almost doubled during the crisis period. Finally, the last loan category of the existing commercial loans includes the long term loans. The majority of them are secured loans with collateral and thus low interest rate. In the expansion period, a strong positive statistically significant effect on the rate of long-term loans is observed. During the crisis period, this positive effect is intensified, but the value of the coefficient (additive effect) is not considered statistically significant.

To sum up, it is observed a strong effect of the interest rate of short term loans on determining the overall lending interest rate, while it follows the effect of the rate of long-term loans. The crisis decreases substantially the effect of short term loans while the effect of the rate of long term loans remains unchanged. 
Table 2. Results of pooled time-series cross-section regression, 2003:M1-2011:M6 (Fixed-effect and time-effect coefficients not reported)

\begin{tabular}{lll}
\hline Variable & Coefficient & t-statistic \\
\hline Constant & 0.236 & $7.724^{* * *}$ \\
Duration till 1 year & 0.503 & $24.841^{* * *}$ \\
Duration till 1 year ${ }^{*} D$ & -0.153 & $-7.602^{* * *}$ \\
Duration 1 to 5 years & 0.141 & $6.848^{* * *}$ \\
Duration 1 to 5 years ${ }^{*} D$ & 0.112 & $4.069^{* * *}$ \\
Duration up to 5 years & 0.320 & $27.711^{* * *}$ \\
Duration up to 5 years $* D$ & 0.061 & 1.828 \\
$\boldsymbol{R}^{2}$ & 0.999 & \\
Observations & 102 & \\
\hline
\end{tabular}

Notes: Dependent variable: Total rate, Independent variables: Duration till 1 year, Duration 1 to 5 years, Duration up to 5 years, D: dummy variable taking the value of 1 for crisis, 0 otherwise.

\section{Summary - Discussion}

This paper reports generally a significant reduction in the supply of loans by the Greek banks. This reduction is started by the autumn of 2009, at which a slowdown in credit growth is appeared. In particular, the banking industry after an intense period of expansion entered into a period of tight liquidity, increased non-performing loans and limited profitability. As a result of the crisis, banks reduced credit provision (i,e. new loans while they blocked existing credit lines) and set stricter credit criteria thus diversifying their lending policy. The study provides strong evidence of credit crunch implications in the domestic banking system and confirms the interaction of economic cycles and bank credit cycles. Moreover, the study reveals increased interest rates from autumn 2009 onwards, especially in the pricing of new loans, although the base rate (i.e. Euribor) that period remained at the same level. Finally, the paper finds that the bargaining power of large borrowers during the crisis causes the negative effect of large loans in the total lending rate.

The study findings have important policy and management implications. In particular, it reveals the adopted bank management strategy that Greek Banks followed given the occurrence of crisis. The Greek banks in order to react to the declined revenues and to stabilize their profits passed on the increased cost of funding from the interbank markets, initially to new borrowers and later -through a repricing mechanism - to the existing loan portfolio. In view of the above, the paper contributes to the thorough understanding of changes in bank credit strategies due to crisis for designing appropriate policies aiming to ensure financial stability in Greece and in other euro area periphery economies in the post crisis era. A possible limitation of this paper is that utilizes data until 2011, thus the effect of the deep recession period is not incorporated into the analysis.

\section{References}

Asea, P \& Bloomber, B (1998). Lending Cycles. Journal of Econometrics, 83, 89-128. http://dx.doi.org/10.1016/S0304-4076(97)00066-3

Bank of Greece. (July 2010). Financial Stability Report, Bank of Greece, Athens. Available at: http://www.bankofgreece.gr/BogEkdoseis/fstability201007_en.pdf.

Bernanke, B. \& Lown, C. (1991). The Credit Crunch, Brookings Papers on Economic Activity 2, 205-239. http://dx.doi.org/10.2307/2534592

Black, S. \& Strahan, P. (2002). Entrepreneurship and Bank Credit Availability. Journal of Finance, 57(6), 2807-2833. http://dx.doi.org/10.1111/1540-6261.00513

Burgstaller, J. \& Scharler, J. (2009). How Do Bank Lending Rates and the Supply of Loans React to Shifts in Loan Demand in the U.K.?

Calomiris, C. \& Mason, J. (2003). Consequences of Bank Distress during the Great Depression. American Economic Review, 93(3), 937-947.

De Haas, R. \& van Horen, N. (2009a). The crisis as a wake-up call. Do banks tighten lending standards during a 
financial crisis? MPRA Paper No. 16382. Available online at: http://mpra.ub.uni-muenchen.de/16382/ (last access: December 4, 2010).

De Haas, R. \& van Horen, N. (2009b). The crisis as a wake-up call. Do banks increase screening and monitoring during a financial crisis? working paper. http://www.ebrd.com/downloads/research/economics/workingpapers/wp0117.pdf

Dell' Ariccia G, Igan, D \& Laeven, L. (2008). Credit booms and Lending Standards: Evidence from the subprime mortgage market. IMF working paper. http://dx.doi.org/10.5089/9781451869675.001

English, W. B., \& Reid, B. K. (1994). Profits and balance sheet developments at U.S. commercial banks in 1993. Federal Reserve Bulletin, 80(6), 483-507.

Guttentag, J., \& Herring, R. (1984). Credit rationing and financial disorder. Journal of Finance, 39(5), 1359-1382. http://dx.doi.org/10.1111/j.1540-6261.1984.tb04912.x

Holmstrom, B., \& Tirole, J. (1997). Financial intermediation, loanable funds, and the real sector. Quarterly Journal of Economics, 112(3), 663-691. http://dx.doi.org/10.1162/003355397555316

Ivashina, V. \& Scharfstein, D. (2009). Bank lending during the financial crisis of 2008, Harvard Business School Working Paper. http://dx.doi.org/10.1111/j.1540-6261.1984.tb04912.x

Kwan S.H. (2010). Financial Crisis and Bank Lending. Working Paper 201011, Federal Reserve Bank of San Francisco. http://dx.doi.org/10.2139/ssrn.1571595

Mojon, B. (2000). Financial structure and the interest rate channel of ECB monetary policy. Working Paper No. 40, European Central Bank, Frankfurt.

Nehls, H., \& Schmidt, T. (2004). Credit crunch in Germany? Kredit und Kapital, 37(4), 479-499.

Peek, J. \& Rosengren, E. (2000). Collateral Damage: Effects of the Japanese Bank Crisis on Real Activity in the United States. American Economic Review, 90, 30-45. http://dx.doi.org/10.1257/aer.90.1.30

Rajan, R. G. (1994). Why bank credit policies fluctuate: A theory and some evidence. Quarterly Journal of Economics, 109, 399-441. http://dx.doi.org/10.1257/aer.90.1.30

Shaffer, S. \& Hoover, S. (2008). Endogenous screening, credit crunches, and competition in laxity. Review of Financial Economics, 17, 296-314. http://dx.doi.org/10.1016/j.rfe.2007.09.001

Tornell, A., Westermann, F. \& Martinez, L. (2004). NAFTA and Mexico's lessthan-stellar performance. NBERWorking Paper \#10289. http://dx.doi.org/10.1016/j.rfe.2007.09.001

Weinberg, J.A. (1995). Cycles in lending standards? Economic Quarterly - Federal Reserve Bank of Richmond, 81(3), 1-18. 


\section{Appendix A}

First Regression: Descriptive Statistics

\begin{tabular}{|c|c|c|c|c|c|c|c|c|c|}
\hline Total rate & & Loan till 1mill & & $\begin{array}{l}\text { Loan up to } \\
1 \text { mill }\end{array}$ & & Commit Rate & & $\begin{array}{l}\text { Non } \\
\text { Commit } \\
\text { Rate }\end{array}$ & \\
\hline Mean & 5.525 & Mean & 982.812 & Mean & 1697.982 & Mean & 6.960 & Mean & 4.737 \\
\hline Standard Error & 0.077 & Standard Error & 21.360 & Standard Error & 51.371 & $\begin{array}{l}\text { Standard } \\
\text { Error }\end{array}$ & 0.058 & $\begin{array}{l}\text { Standard } \\
\text { Error }\end{array}$ & 0.087 \\
\hline Median & 5.260 & Median & 968.507 & Median & 1655.631 & Median & 7.026 & Median & 4.465 \\
\hline Mode & 5.160 & Mode & \#N/A & Mode & \#N/A & Mode & \#N/A & Mode & \#N/A \\
\hline $\begin{array}{l}\text { Standard } \\
\text { Deviation }\end{array}$ & 0.733 & $\begin{array}{l}\text { Standard } \\
\text { Deviation }\end{array}$ & 202.635 & $\begin{array}{l}\text { Standard } \\
\text { Deviation }\end{array}$ & 487.346 & $\begin{array}{l}\text { Standard } \\
\text { Deviation }\end{array}$ & 0.552 & $\begin{array}{l}\text { Standard } \\
\text { Deviation }\end{array}$ & 0.829 \\
\hline $\begin{array}{l}\text { Sample } \\
\text { Variance }\end{array}$ & 0.537 & $\begin{array}{l}\text { Sample } \\
\text { Variance }\end{array}$ & 41.061 & $\begin{array}{l}\text { Sample } \\
\text { Variance }\end{array}$ & 237.506 & $\begin{array}{l}\text { Sample } \\
\text { Variance }\end{array}$ & 0.304 & $\begin{array}{l}\text { Sample } \\
\text { Variance }\end{array}$ & 0.688 \\
\hline Kurtosis & -0.807 & Kurtosis & -0.024 & Kurtosis & 1.764 & Kurtosis & -0.134 & Kurtosis & -0.899 \\
\hline Skewness & 0.388 & Skewness & 0.039 & Skewness & 1.016 & Skewness & -0.654 & Skewness & 0.562 \\
\hline Range & 2.920 & Range & 1011.02 & Range & 2582.563 & Range & 2.213 & Range & 3.294 \\
\hline Minimum & 4.160 & Minimum & 500.732 & Minimum & 817.681 & Minimum & 5.723 & Minimum & 3.314 \\
\hline Maximum & 7.080 & Maximum & 1511.75 & Maximum & 3400.244 & Maximum & 7.936 & Maximum & 6.608 \\
\hline Sum & 497.3 & Sum & 88453.1 & Sum & 152818.4 & Sum & 626.4 & Sum & 426.4 \\
\hline Count & 90 & Count & 90 & Count & 90 & $\begin{array}{l}\text { Count } \\
\text { Confidence }\end{array}$ & 90 & $\begin{array}{l}\text { Count } \\
\text { Confidence }\end{array}$ & 90 \\
\hline $\begin{array}{l}\text { Confidence } \\
\text { Level }(95.0 \%)\end{array}$ & 0.153 & $\begin{array}{l}\text { Confidence } \\
\text { Level }(95,0 \%)\end{array}$ & 42.441 & $\begin{array}{l}\text { Confidence } \\
\text { Level }(95,0 \%)\end{array}$ & 102.073 & $\begin{array}{l}\text { Level } \\
(95.0 \%)\end{array}$ & 0.116 & $\begin{array}{l}\text { Level } \\
(95.0 \%)\end{array}$ & 0.174 \\
\hline
\end{tabular}

Residuals of the regression (new loans)

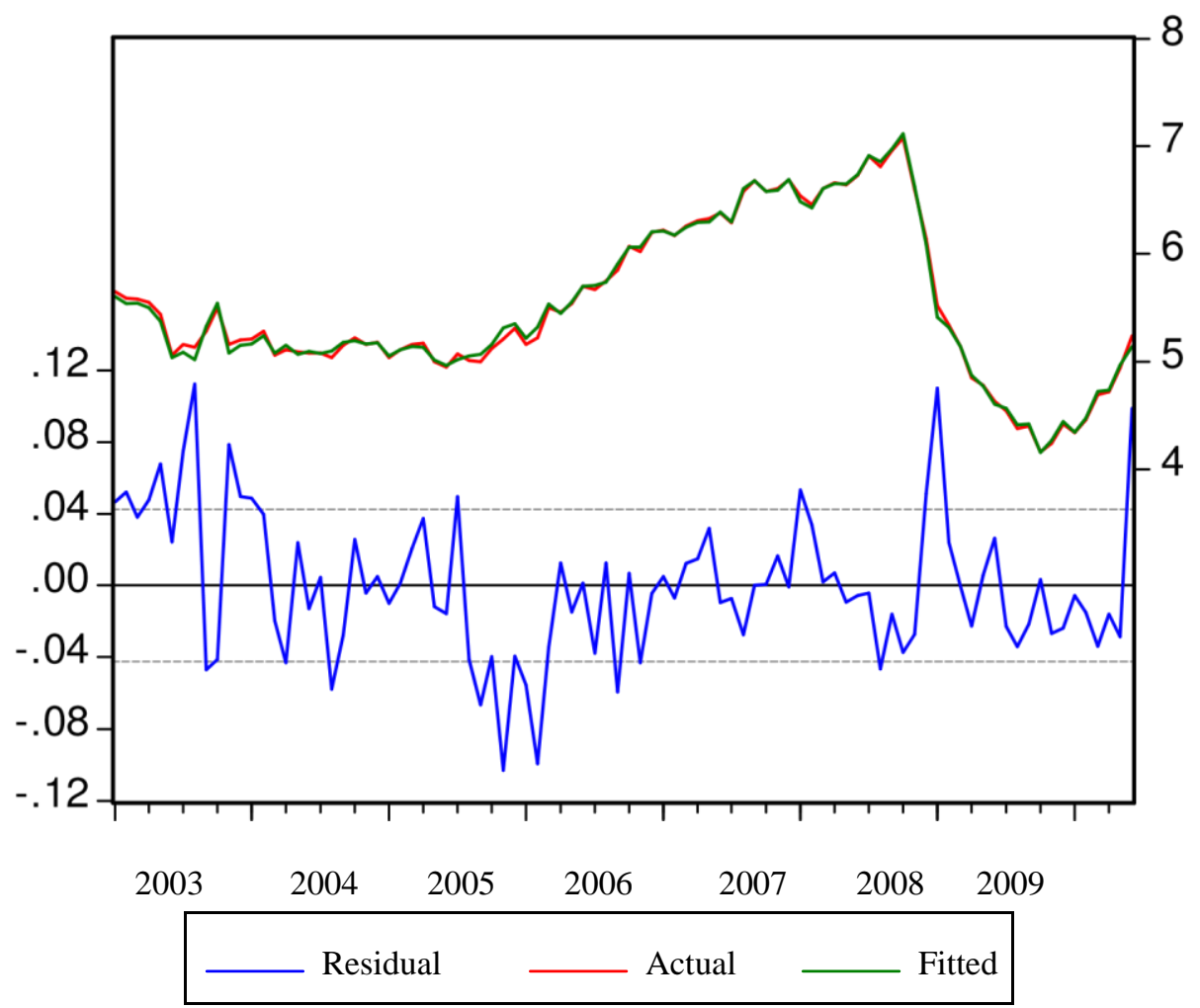




\section{Appendix B}

Second Regression: Descriptive Statistics

\begin{tabular}{|c|c|c|c|c|}
\hline Total rate & Dur till 1y & Dur $1 y-5 y$ & Dur up to $5 y$ & \\
\hline Mean & 5.869 Mean & 6.303 Mean & 5.595 Mean & 5.296 \\
\hline Standard Error & $0.071^{\text {Standard Error }}$ & $0.067^{\text {Standard Error }}$ & $0.096^{\text {Standard Error }}$ & 0.071 \\
\hline Median & 5.600 Median & 6.064 Median & 5.377 Median & 5.183 \\
\hline Mode & 5.510 Mode & Mode & Mode & \#N/A \\
\hline $\begin{array}{l}\text { Standard } \\
\text { Deviation }\end{array}$ & $\begin{array}{c}\text { Standard } \\
0.676 \text { Deviation }\end{array}$ & $\begin{array}{c}\text { Standard } \\
0.637 \text { Deviation }\end{array}$ & $\begin{array}{c}\text { Standard } \\
0.911 \text { Deviation }\end{array}$ & 0.676 \\
\hline Sample Variance & $0.456{ }^{\text {Sample Variance }}$ & $0.4066^{\text {Sample Variance }}$ & 0.829 Sample Variance & 0.457 \\
\hline Kurtosis & -0.867 Kurtosis & -0.810 Kurtosis & -0.567 Kurtosis & -0.784 \\
\hline Skewness & 0.343 Skewness & 0.784 Skewness & -0.131 Skewness & -0.088 \\
\hline Range & 2.530 Range & 2.202 Range & 3.203 Range & 2.543 \\
\hline Minimum & 4.710 Minimum & 5.588 Minimum & 3.847 Minimum & 3.989 \\
\hline Maximum & 7.240 Maximum & 7.791 Maximum & 7.049 Maximum & 6.532 \\
\hline Sum & 528.230 & 567.263 & 503.587 & 476.678 \\
\hline Count & 90 Count & 90 Count & 90 Count & 90 \\
\hline $\begin{array}{l}\text { Confidence } \\
\text { Level }(95.0 \%)\end{array}$ & $\begin{array}{c}\text { Confidence } \\
0.142 \text { Level }(95.0 \%)\end{array}$ & $\begin{array}{l}\text { Confidence Level } \\
0.133(95.0 \%)\end{array}$ & $\begin{array}{l}\text { Confidence Level } \\
0.191(95.0 \%)\end{array}$ & 0.142 \\
\hline
\end{tabular}

Residuals of the regression (existing loans )

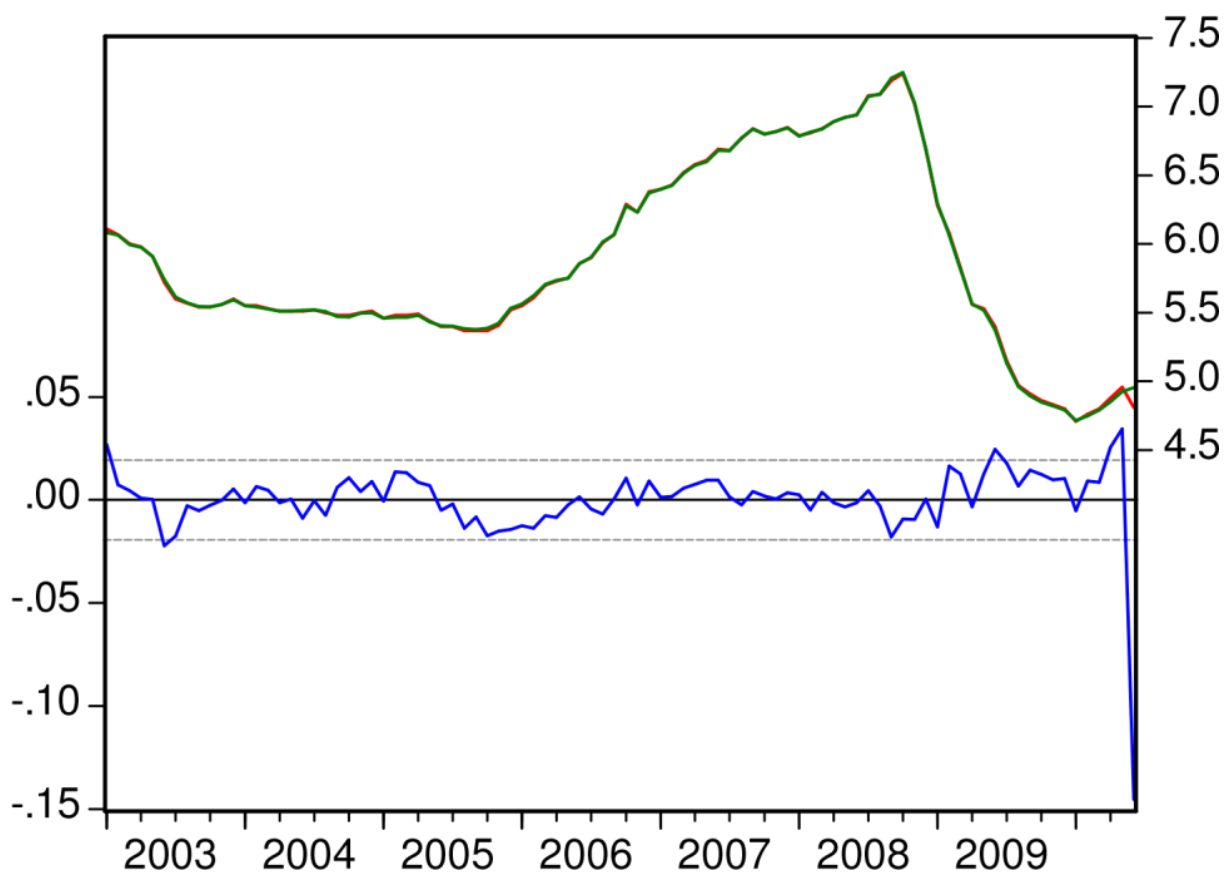
Residual
Actual
Fitted 